\title{
Muatan Kearifan Lokal Cerpen Indonesia
}

\author{
Sulastriningsih Djumingin ${ }^{1}$ \\ Juanda ${ }^{2}$ \\ Azis $^{3}$
}

\section{${ }^{123}$ Fakultas Bahasa dan Sastra, Universitas Negeri Makassar}

\author{
${ }^{1}$ sulastriningsih77@gmail.com ${ }^{1}$ \\ 2 juanda@unm.ac.id \\ 3 azis@unm.ac.id ${ }^{3}$
}

\begin{abstract}
Abstrak
Penelitian ini memiliki keunggulan karena dapat dijadikan sebagai acuan dalam pembinaan karakter manusia di perguruan tinggi. Desain penelitian yang menggambarkan penelitian secara objektif. Peneliti mengamati secara mendalam dan melakukan analisis guna menemukan muatan kearifan lokal dan pendidikan karakter dalam cerpen Indonesia. Pengumpulan data referensi yang relevan dengan objek peneliti, memilah dan mengkategorisasikan data yang ditemukan, mengolah data, dan selanjutnya menyajikan data secara objektif. Hasil penelitian yaitu: Kemampuan mahasiswa dalam jenis muatan kearifan lokal yang terdapat dalam cerpen Indonesia adalah sebagai berikut: Jenis budaya: tinggi 55 (34,38\%), sedang $45(28,13 \%)$, dan rendah $60(37,5 \%)$, jenis norma: tinggi $60(37,5 \%)$, sedang $45(28,13 \%)$, dan rendah 55 (34,38\%), jenis etika: tinggi $55(34,38 \%)$, sedang $50(31,25 \% \%)$ dan rendah 55 $(34,38 \%)$, jenis kepercayaan: tinggi 65 (41\%), sedang $45(28 \%)$, dan rendah $50(31 \%)$, jenis adat istiadat: tinggi $50(31,25 \%)$ sedang $60(37,5 \% \%)$ dan rendah $50(31,25)$, jenis karakter rasa ingin tahu mencapai tinggi 100 (62,5\%), sedang 40 (25\%), dan rendah 20 $(12,5 \%)$, jenis karakter semangat kebangsaan mencapai tinggi $70(43,75 \%)$, sedang 60 $(37,5 \%)$, dan rendah $30(18,75 \%)$, jenis karakter cinta tanah air mencapai tinggi 60 (37,5\%), sedang $50(31,25 \%)$, dan rendah $50(31,25 \%)$, dan rendah $50(31,25 \%)$, jenis karakter menghargai prestasi mencapai tinggi $70(43,75 \% 0$, sedang $50(31,25 \%)$, dan rendah 40 (25\%). jenis karakter bersahabat mencapai tinggi 100 (62,5\%), sedang 30 (18,75\%), dan rendah 30 (18,75\%), jenis karakter cinta damai mencapai 60 (37,5\%), sedang $50(31,25 \%)$, dan redah $50(31,25 \%)$, jenis karakter gemar membaca mencapai tinggi $150(93,75 \%)$, sedang $10(6,25)$, jenis karakter peduli lingkungan mencapai tinggi $150(93,75 \%)$, sedang $10(6,25 \%)$, jenis karakter peduli social mencapa itinggi 150 $(93,75 \%)$ sedang $10(6,25 \%)$, dan jenis karakter tanggung jawab mencapai tinggi 100 $(100 \%)$, sedang sedang dan rendah $0(0 \%)$.
\end{abstract}

Kata Kunci: kearifan, Lokal, cerpen

\section{Pendahuluan}

Era globalisasi telah membawa pengaruh di seluruh aspek kehidupan masyarakat yang akan membawa citra global dengan budaya lokal yang bertolak belakang dengan budaya lokal. Revolusi informasi dan komunikasi yang menjadi dampak langsung dari kemajuan ilmu pengetahuan dan teknologi telah menghilangkan batasan-batasan region 
dan kewilayahan. Bagi masyarakat tertentu, kondisi ini harus disikapi dengan cepat agar mereka tidak melupakan nilai kearifan lokal budayanya.

Kearifan lokal merupakan pemikiran atau gagasan masyarakat setempat yang dijadikan sebagai pedoman hidup yang ditanamkan dalam diri manusia sejak dini, sehingga konsep budaya telah berakar dan akan membentuk karakter diri sebagai identitasnya. Keberadaan kearifan lokal dapat dilihat dari nilai-nilai yang terkandung dalam masyarakat tertentu. Nilai-nilai tersebut menjadi pegangan hidup yang tak terpisahkan dari masyarakat tersebut.

Wujud kearifan lokal dapat berupa tradisi yang tercermin dalam nilai-nilai yang berlaku dalam masyarakat tertentu. Kearifan lokal lebih menggambarkan satu fenomena yang spesifik yang biasanya menjadi ciri dari komunitas masyarakat tertentu. Kearifan juga menjadi entitas masyarakat yang dapat menentukan harkat dan martabat dalam komunitasnya untuk membangun peradaban masyarakat. Salah satu upaya untuk mengatasi merosotnya moral siswa ialah dengan mengoptimalkan bidang pendidikan. Pendidikan karakter dapat diajarkan secara terpadu melalui semua mata pelajaran termasuk mata pelajaran bahasa Indonesia. Mata pelajaran bahasa Indonesia dapat menjadi pintu masuk dalam penanaman kearifan lokal dan nilai-nilai pendidikan karakter, khususnya pada materi cerita rakyat.

Dalam dunia pendidikan, kurikulum merupakan acuan dalam mencapai visi misi pendidikan nasional. Menurut UU Tahun 1989 Kurikulum yaitu seperangkat rencana dan peraturan mengenai isi dan bahan pelajaran, serta cara yang digunakannya dalam menyelenggarakan kegiatan belajar mengajar. Kurikulum yang digunakan saat ini yaitu Kurikulum 2013 yang menitikberatkan pada tiga ranah yaitu sikap, keterampilan, dan pengetahuan. Kurikulum 2013 menuntut siswa dalam mengembangkan sikap, keterampilan dan pengetahuan. Adapun harapan karakter yang ideal sesuai dengan Kurikulum 2013 yang telah ditetapkan oleh Kementrian Pendidikan Nasional yang dimasukkan dalam sistem terdapat 18 pendidikan karakter nasional yaitu: religius, jujur, toleransi, disiplin, kerja keras, kreatif, mandiri, demokratis, rasa ingin tahu, semangat kebangsaan, cinta tanah air, menghargai prestasi, bersahabat, cinta damai, gemar membaca, peduli lingkungan, peduli sosial, dan tanggung jawab.

Kearifan lokal adalah pandangan hidup dan ilmu pengetahuan serta berbagai strategi kehidupan yang berwujud aktivitas yang dilakukan oleh masyarakat lokal duntu menjawab berbagai masalah dalam pemenuhan kebutuhan mereka. Dalam bahasa asing sering juga dikonsepsikan sebagai kebijakan setempat local wisdom atau pengetahuan setempat local knowledge atau kecerdasan setempat local genious (Fajarini, 2014:123).

Menurut Haryati Soebadio (dalam Agus Wibowo, 2015) Kearifan lokal merupakan sebuah identitas atau kepribadian budaya sebuah bangsa yang menyebabkan bangsa tersebut mampu menyerap, bahkan mengolah kebudayaan yang berasal dari luar/bangsa lain menjadi watak dan kemampuan sendiri. Kearifan lokal sifatnya menyatu dengan karakter masyarakat, karena keberadaannya selalu dilaksanakan dan dilestarikan dalam kondisi tertentu malah sangat dihormati. Senada dengan Haryati, Suhartini (dalam Agus Wibowo, 2015) mendefinisikan kearifan lokal sebagai sebuah warisan nenek moyang yang berkaitan dengan tata nilai kehidupan. Tata nilai kehidupan ini menyatu tidak hanya dalam bentuk religi, tetapi juga dalam budaya, dan adat istiadat. Ketika sebuah masyarakat melakukan adaptasi terhadap lingkungannya, mereka mengembangkan suatu kearifan baik yang berwujud pengetahuan atau ide, peralatan, dipadu dengan norma adat, nilai budaya, dan aktivitas mengelola lingkungan guna mencukupi kebutuhan hidupnya. 
Kearifan lokal menurut Susanti (dalam Asriati, 2012: 112) ialah gagasan-gagasan setempat yang bersifat bijaksana, penuh kearifan, bernilai baik, yang diikuti oleh anggota masyarakat. Dalam pengertian Kamus Besar Bahasa Indonesia, kearifan lakal (local wisdom) terdiri dari dua kata: kearifan (wisdom) dan lokal (local). Dalam Kamus Inggris Indonesia (John M. Echols dan Hassan Syadily dalam Sartini, 2004: 111) local berarti setempat, sedangkan wisdom (kearifan) sama dengan kebijaksanaan. Secara umum maka local wisdom (kearifan setempat) dapat dipahami sebagai gagasan-gagasan setempat (local) yang bersifat bijaksana, penuh kearifan, bernilai baik, yang tertanam dan diikuti oleh anggota masyarakatnya.

Menurut rumusan yang dikeluarkan oleh Departemen Sosial (sekarang Kementerian Sosial) kearifan lokal diartikan sebagai pandangan hidup dan pengetahuan serta berbagai strategi kehidupan yang berwujud aktivitas yang dilakukan oleh masyarakat lokal dalam menjawab berbagai masalah dalam pemenuhan kebutuhan mereka (Departemen Sosial RI, 2006). Sistem pemenuhan kebutuhan mereka pasti meliputi seluruh unsur kehidupan, agama, ilmu pengetahuan, ekonomi, teknologi, organisasi sosial, bahasa dan komunikasi, serta kesenian.

Pengertian lain namun senada tentang kearifan lokal juga diungkapkan oleh (Zulkarnain dan Febriamansyah dalam Cecep, 2011: 68) berupa prinsip-prinsip dan caracara tertentu yang dianut, dipahami, dan diaplikasikan oleh masyarakat lokal dalam berinteraksi dan berinterelasi dengan lingkungannya dan ditransformasikan dalam bentuk sistem nilai dan norma adat. Adapun, (Kongprasertamorn dalam Cecep, 2011: 68) berpendapat bahwa kearifan lokal mengacu pada pengetahuan yang datang dari pengalaman suatu komunitas dan merupakan akumulasi dari pengetahuan lokal. Kearifan lokal itu terdapat dalam masyarakat, komunitas, dan individu.

Berdasarkan pendapat para ahli di atas, peneliti dapat mengambil kesimpulan bahwa kearifan lokal merupakan pikiran-pikiran atau gagasan yang timbul dan berkembang secara terus-menerus di dalam sebuah masyarakat berupa nilai-nilai norma, bahasa, adat-istiadat, kepercayaan, dan kebiasaan sehari-hari. Kearifan lokal juga merupakan salah satu sarana untuk mengolah kebudayaan daerah agar terhindar dari kebudayaan orang asing.

Ahli antropologi telah mengkategorisasikan kebudayaan manusia yang menjadi wadah kearifan lokal itu, aktivitas sosial, dan artefak. Kebudayaan merupakan keseluruhan pengetahuan yang dimiliki oleh sekelompok manusia dan dijadikan sebagai pedoman hidup untuk menginterpretasikan lingkungannya dalam bentuk tindakantindakannya sehari-hari. Seperti dipaparkan oleh Koentjaraningrat (2002: 45) "Bahwa kata kebudayaan berasal dari bahasa sansekerta Buddhayah, adalah bentuk jamak dari Buddhi yang berarti budi atau akal. Demikian, kebudayaan itu dapat diartikan hal-hal yang bersangkutan dengan budi dan akal. Adapun istilah Culture, sama artinya dengan kebudayaan, yaitu dari kata latin colere yang berarti mengolah atau mengerjakan".

Budaya itu sendiri merupakan suatu produk dari akal budi manusia setidaknya apabila dilakukan pendekatan secara etimologi. Budaya dalam hal ini disebut kebudayaan sangat erat kaitannya dengan masyarakat. Dalam pergiliran budaya antargenerasi ini dibutuhkan adanya generasi perantara yang sudah mampu melakukan pemahaman dari generasi tua dan mampu mengomunikasikan ke dalam bahasa yang ringan dan mudah dimengerti oleh generasi selanjutnya (Irwan, 2009).

a) Norma

Norma didefinisikan sebagai aturan atau ketentuan yang mengikat warga kelompok di masyarakat, dipakai sebagai panduan, tatanan, dan kendalian tingkah laku, yang sesuai dan berterima (Kementrian Pendidikan Nasional: 2014). Norma adalah 
petunjuk tingkah laku yang harus dilakukan dan tidak boleh dilakukan dalam hidup sehari-hari, berdasarkan suatu alasan (motivasi) tertentu dengan disertai sanksi. Sanksi adalah ancaman/akibat yang akan diterima apabila norma tidak dilakukan (Widjaja, 1985: 168).

b) Etika

Etika yaitu Ilmu tentang apa yang baik dan apa yang buruk dan tentang hak dan kewajiban moral (akhlak) (Kementrian Pendidikan Nasional2014). Secara etimologi kata "etika" berasal dari bahasa Yunani yang terdiri dari dua kata yaitu Ethos dan ethikos. Ethos berarti sifat, watak kebiasaan, tempat yang biasa. Ethikos berarti susila, keadaban, kelakuan dan perbuatan yang baik (Lorens, 2000: 217). Sedangkan dalam bahasa Arab kata etika dikenal dengan istilah akhlak, artinya budi pekerti. Sedangkan dalam bahasa Indonesia disebut tata susila (Hasbullah, 1978: 9).

Kebiasaan hidup yang baik ini lalu dibekukan dalam bentuk kaidah, aturan atau norma yang disebarluaskan, dikenal, dipahami, dan diajarkan secara lisan dalam masyarakat. Kaidah, norma atau aturan ini pada dasarnya, menyangkut baik-buruk perilaku manusia. Atau, etika dipahami sebagai ajaran yang berisikan perintah dan larangan tentang baik-buruknya perilaku manusia, yaitu perintah yang harus dipatuhi dan larangan yang harus dihindari (Keraf, 2002: 2).

c) Kepercayaan

Kepercayaan berarti anggapan atau keyakinan bahwa sesuatu yang dipercayai itu benar atau nyata (Kementrian Pendidikan Nasional: 2014). Menurut Ba dan Pavlou (2002) mendefinisikan kepercayaan sebagai penilaian hubungan seseorang dengan orang lain yang akan melakukan transaksi tertentu sesuai dengan harapan dalam sebuah lingkungan yang penuh ketidakpastian.

d) Adat istiadat

Adat-istiadat didefinisikan sebagai tata kelakuan yang kekal dan turun-temurun dari generasi satu ke generasi lain sebagai warisan hingga kuat integrasinya dengan pola perilaku masyarakat (Kementrian Pendidikan Nasional: 2014). Menurut JC. Mokoginta (1996:77), "adat istiadat adalah bagian dari tradisi yang sudah mencakup dalam pengertian kebudayaan. Karena itu, adat atau tradisi ini dapat dipahami sebagai pewarisan atau penerimaan norma-norma adat istiadat".

e) Hukum Adat

Menurut (Hardjito Notopuro, 1996: 49) hukum adat adalah hukum tak tertulis, hukum kebiasaan dengan ciri khas yang merupakan pedoman kehidupan rakyat dalam rnenyelenggarakan tata keadilan dan kesejahteraan masyarakat dan bersifat kekeluargaan. Van Vollenhoven (1987:6) menjelaskan bahwa "Hukum adat adalah hukum yang tidak tertulis yang tidak bersumber pada peraturan-peraturan yang dibuat oleh pemerintah Hindia Belanda dahulu atau alat-alat kekuasaan lainnya yang diadakan sendiri oleh kekuasaan Belanda dahulu"

Pendidikan karakter merupakan proses yang berkelanjutan dan tak pernah berakhir (never ending process), sehingga menghasilkan perbaikan kualitas yang berkesinambungan (continuous quality improvement), yang ditujukan pada terwujudnya sosok manusia masa depan, dan berakar pada nilai-nilai budaya bangsa (Mulyasa, 2011:2) Pendidikan karakter harus menumbuhkembangkan nilai-nilai filosofis dan mengamalkan seluruh karakter bangsa secara utuh dan menyeluruh (Kaffah). Sekarang, ketika masyarakat dan bangsa dilanda krisis moral, sistem nilai tersebut perlu direvitalisasi, terutama dalam mewujudkan karakter pribadi dan karakter bangsa yang telah ada seperti tekun beribadah, jujur dalam ucapan dan tindakan, berpikir posistif, dan 
rela berkorban. Semua itu merupakan karakter luhur bangsa Indonesia yang sekarang sudah hampir punah (Saktya, 2017: 370).

Pendidikan karakter menurut Lickona (dalam Daniah, 2016: 5) adalah pendidikan untuk membentuk kepribadian seseorang melalui pendidikan budi pekerti yang hasilnya terlihat dalam tindakan nyata seseorang, yaitu tingkah laku yang baik, jujur, bertanggung jawab, menghormati hak orang lain, kerja keras, dan sebagainya.

Secara implisit ditegaskan dalam Rencana Pembangunan Jangka Panjang Nasional (RPJPN) tahun 2005-2025, pendidikan karakter ditempatkan sebagai landasan untuk mewujudkan visi pembangunan nasional, yaitu "Mewujudkan masyarakat berakhlak mulia, bermoral, beretika, berbudaya, dan beradab berdasarkan falsafah pancasila.

Sementara dalam Undang-Undang Republik Indonesia Nomor 20 Tahun 2003 tentang Sistem Pendidikan Nasional yang berbunyi "Pendidikan nasional berfungsi mengembangkan kemampuan dan membentuk watak serta peradaban bangsa yang bermartabat dalam rangka mencerdaskan kehidupan bangsa, bertujuan untuk berkembangnya potensi peserta didik agar menjadi manusia yang beriman dan bertakwa kepada Tuhan Yang Maha Esa, berakhlak mulia, sehat, berilmu, cakap, kreatif, mandiri, dan menjadi warga negara yang demokratis serta bertanggung jawab".

\section{Metode Penelitian}

Jenis penelitian yang digunakan adalah penelitian kualitatif dengan pemaparan data deskriptif. Dikatakan demikian, karena setiap data yang didapatkan akan dideskripsikan dalam bentuk verbal dengan analisis nonstatistik. Penelitian ini juga menggunakan penelitian kuantitatif. Penelitian ini akan mendeskripsikan muatan kearifan lokal dan pendiidkan karakter yang terdapat dalam cerpen Indonesia.

Penelitian ini menggunakan desain deskriptif kualitatif dan kuantitatif Desain ini menggunakan rancangan penelitian yang menggambarkan penelitian secara objektif. Peneliti akan mengamati secara mendalam dan melakukan analisis mendalam terhadap objek penelitian guna menemukan muatan kearifan lokal dan pendidikan karakter dalam cerpen Indonesia tersebut. Dalam penerapan desain penelitian ini yang pertama kali dilakukan oleh peneliti adalah mengumpulkan data dan referensi yang relevan dengan objek peneliti, memilah dan mengkategorisasikan data yang ditemukan, mengolah data, dan selanjutnya menyajikan data secara objektif sesuai dengan hasil interpretasi terhadap objek penelitian yang dilakukan oleh peneliti.

Fokus penelitian ini yaitu: (1) Analisis muatan kearifan lokal yang terdapat dalam cerpen Indonesia, (2) Analisis pendidikan karakter yang terdapat dalam cerpen Indonesia, (3) Implementasi muatan kearifan lokal dalam pembelajaran prosa fiksi mahasiswa jurusan bahasa Indonesia UNM. Data dalam penelitian ini ada dua yaitu: (1) Kata-kata atau kalimat yang mengandung muatan kearifan lokal dan pendidikan karakter yang terdapat dalam cerpen Indonesia dan (2) Kata-kata atau kalimat yang mengandung implementasi pembelajarannya. Sumber data penelitian ini adalah cerpen yang ada di Kompas, Republika, Tempo, dan Media Indonesia. Instrumen adalah alat bantu yang digunakan oleh peneliti saat menerapkan suatu metode dalam melakukan penelitian. Alat yang digunakan dalam penelitian ini adalah peneliti sebagai instrumen kunci, alat bantu kartu untuk catatan, pengelompokan inventarisasi data, dan analisis data. Pengumpulan data penelitian ini menggunakan teknik baca-simak, catat.

Suatu penelitian pasti memiliki unsur persiapan, pelaksanaan, dan pelaporan hasil penelitian. Penelitian ini melalui serangkaian tahapan yang ditempuh yaitu:

(1) Mengumpulkan teks cerpen. 
(2) Menentukan jumlah subjek penelitian ini yaitu jumlah teks cerpen yang akan dianalisis

(3) Mengklasifikasi data yang sesuai dengan struktur isi teks cerpen.

(4) Mengidentifikasi muatan kearifan lokal dan pendidikan karakter pada data yang sesuai dengan struktur isi teks cerpen.

(5) Mengidentifikasi implementasi muatan kearifan lokal dan pendidikan karakter dalam pembelajaran prosa fiksi.

(6) Mengambil kutipan yang sesuai dengan muatan nilai kearifan lokal dan pendidikan karakter

(7) Pengodean data, yaitu aktivitas memberi kode terhadap segmen-segmen data. Pada penelitian ini diberikan kode.

(8) menganalisis data dan memaparkan temuan

(9) mendeskripsikan hasil klasifikasi dan analisis data sesuai dengan fokus dalam penelitian.

\section{Hasil}

\section{Muatan Kearifan Lokal yang Terdapat dalam Cerpen Indonesia}

\section{a. Kemampuan Mahasiswa Tentang Jenis Cerpen}

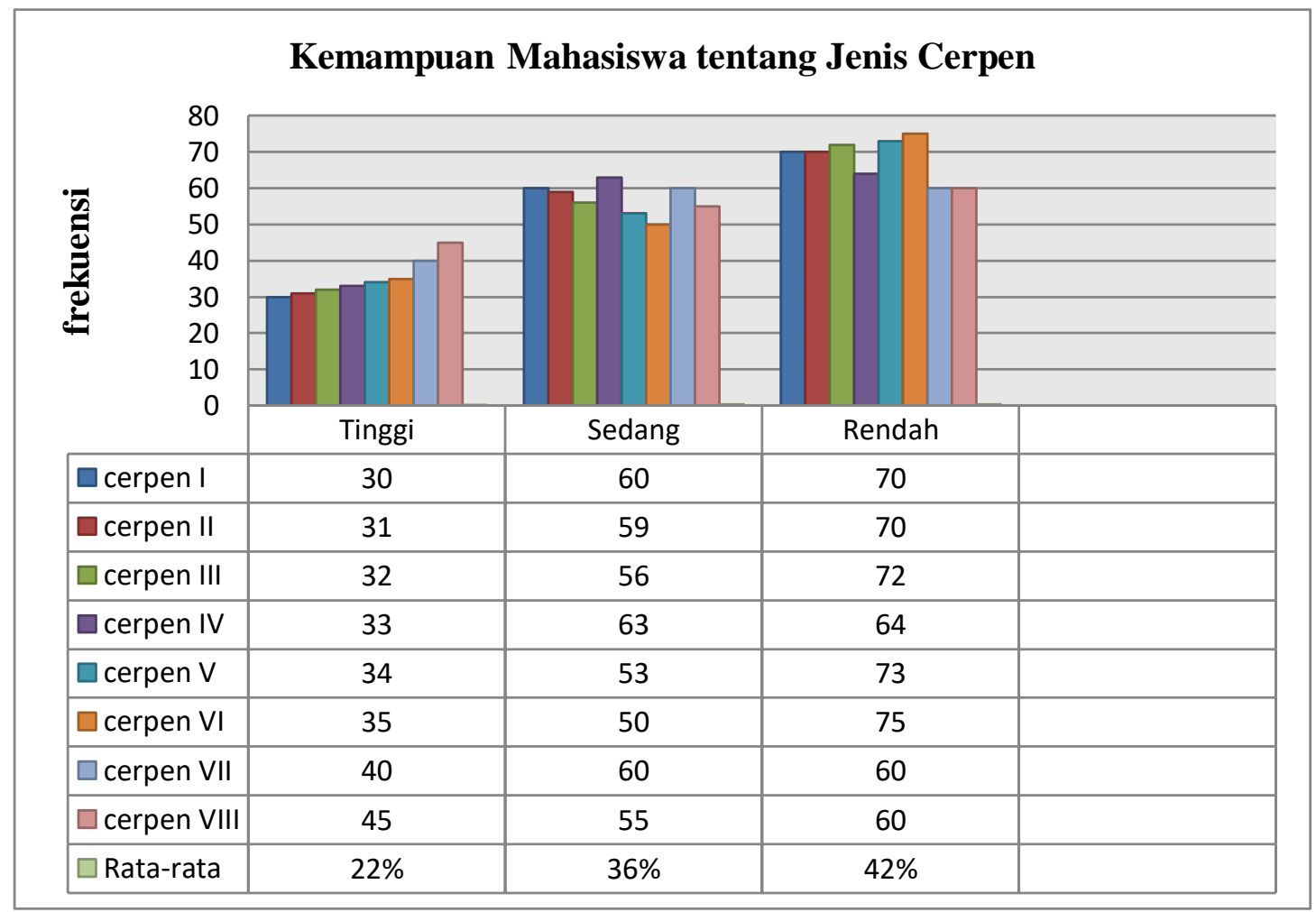

Kemampuan mahasiswa tentang jenis cerpen Indonesia adalah: Cerpen 1 Tinggi 30 (18\%) , sedang 60 (38\%), dan rendah 70 (44\%), jeis cerpen II: tinggi 31 (19\%), sedang 59 (37\%), dan rendah 70 (44\%), jneis cerpen III:tinggi 32 920\%), sedang 56 (35\%), dan rendah 72 (45\%), jenis cerpen IV: tinggi 33 (21\%), sedang 53(33\%), dan rendah 64 (40\%), jenis cerpen V: tinggi 34 (21\%), sedang 53 (33\%), dan rendah 73 (46\%), jenis cerpen VI: tinggi 35 (22\%), sedang 50 (31\%) dan rendah 75 (41\%), jenis cerpen VII: tinggi 
ISSN 2443-3667 (print) 2715-4564 (online)

40 (25\%), sedang 60 (38\%), dan rendah 60 (38\%), jenis cerpen VIII: tinggi 45 (28\%), sedang 55 (34\%), dan rendah 60 (38\%). Jadi rata-rata 22\% yag tinggi, 36\% yang sedang, dan $42 \%$ yang rendah.

\section{b. Kemampuan Mahasiswa Tentang Jenis Kearifan Lokal}

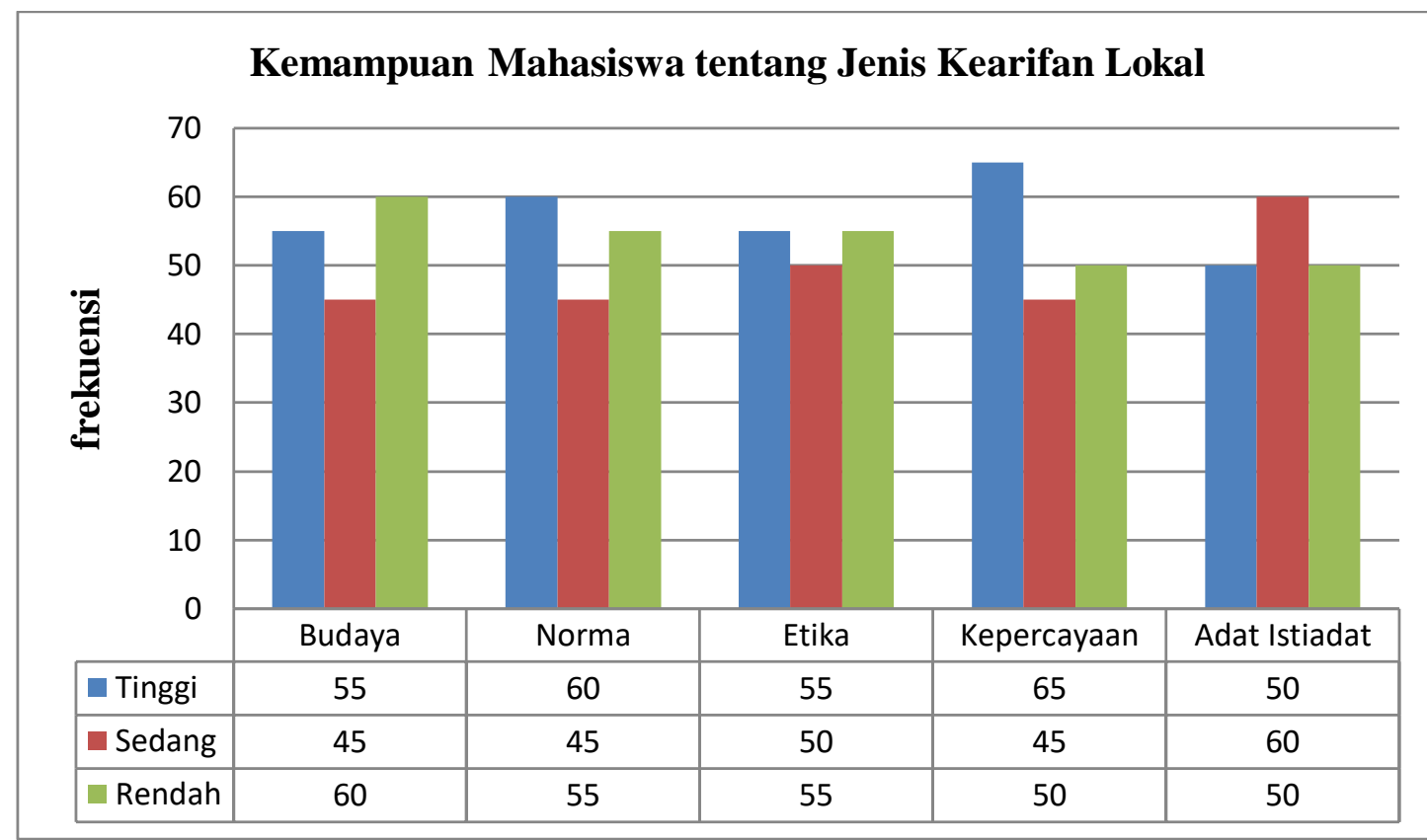

Kemampuan mahasiswa dalam jenis muatan kearifan lokal yang terdapat dalam cerpen Indonesia adalah sebahagai berikut: Jenis budaya: tinggi 55 (34,38\%), sedang 45 $(28,13 \%)$, dan rendah 60 (37,5\%), jenis norma: tinggi 60 (37,5\%), sedang $45(28,13 \%)$, dan rendah 55 (34,38\%), jenis etika: tinggi 55 (34,38\%), sedang 50 (31,25\%\%) dan rendah 55 (34,38\%), jenis kepercayaan: tinggi 65 (41\%), sedang 45 (28\%), dan rendah $50(31 \%)$, jenis adat istiadat: tinggi $50(31,25 \%)$ sedang $60(37,5 \% \%)$ dan rendah 50 $(31,25)$.

C. Kemampuan Mahasiswa Tentang Pendidikan Karakter

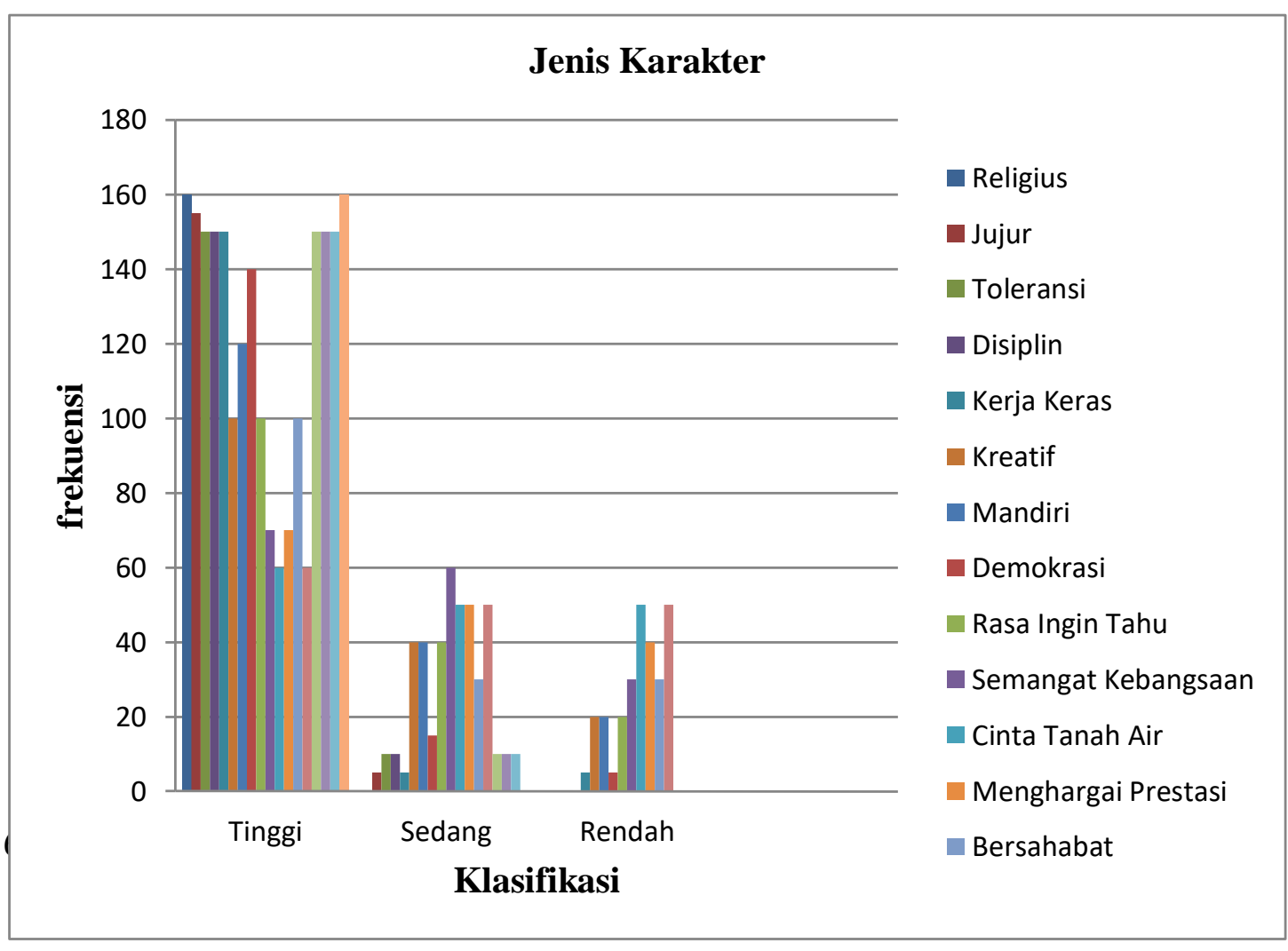


Jenis Karakter Religius mencapai tinggi 160 (100\%), sedang dan rendah 0(0\%), Jenis karakter jujur mencapai tinggi 155 (96,87\%), sedang $5(3,13 \% 0$, dan rendah $0(0 \%)$, jenis karakter toleransi mencapai tinggi 150 (93,75\%), sedang $10(6,25 \%)$ dan rendah $0(0 \%)$, jenis karakter didiplin mencapai tinggi 150 (93,75\%), sedang 10 (6,25\%0, jenis karakter kerja keras mencapai tinggi 150 (93,75\%), sedang 5 (3,13\%), rendah 5 (3,13\%), jenis karakter kreatif mencapai tinggi 100 (62,5\%),sedang 40 (25\%), dan rendah 20 (12,5\%), jenis karakter mandiri mencapai tinggi 120 (75\%), sedang 20 (12,5\%), dan rendah20 (12,5\%), jenis karakter demokrasi mencapai tinggi 140 (87,5\%), sedang 15 (9,37\%) dan rendah $5(3,13 \%)$, jenis karakter rasa ingi tahu mencapai tinggi $100(62,5 \%)$, sedang 40 (25\%), dan rendah $20(12,5 \%)$, jenis karakter senagat kebangsaan mencapai tinggi 70 $(43,75 \%)$, sedang $60(37,5 \%)$, dan rendah $30(18,75 \%)$, jenis karakter cinta tanah air mencapai tinggi 60 (37,5\%), sedang 50 (31,25\%), dan rendah 50 (31,25\%), , dan rendah $50(31,25 \%)$, jenis karakter menghargai prestasi mencapai tinggi $70(43,75 \% 0$, sedang 50 (31,25\%), dan rendah 40 (25\%). jenis karakter bersahabat mencapai tinggi 100 (62,5\%), sedang $30(18,75 \%)$, dan rendah 30 (18,75\%), jenis karakter cinta damai mencapai 60 $(37,5 \%)$, sedang $50(31,25 \%)$, dan redah 50 (31,25\%), jenis karakter gemar membaca mencapai tinggi $150(93,75 \%)$, sedang $10(6,25)$, jenis karakter peduli lingkungan mencapai tinggi 150 (93,75\%), sedang 10 (6,25\%), jenis karakter peduli sosial mencapa tinggi $150(93,75 \%)$ sedang $10(6,25 \%)$, dan jenis karakter tanggung jawab mencapai tinggi $100(100 \%)$, sedang sedang dan rendah $0(0 \%)$.

\section{Pembahasan}

Hasil analisis data menunjukkan bahwa nilai kearifan lokal yang dominan digunakan dalam cerita rakyat pada buku teks Bahasa Indonesia Kelas X adalah nilai norma yaitu aturan atau ketentuan yang mengikat warga kelompok di masyarakat, dipakai sebagai panduan, tatanan, dan kendalian tingkah laku, yang sesuai dan berterima (Departemen Pendidikan Nasional, 2014). Hasil analisis data juga menunjukkan bahwa nilai pendidikan karakter yang digunakan dalam cerita rakyat pada buku teks Bahasa Indonesia Kelas X adalah nilai religius yakni ketaatan dan kepatuhan dalam memahami dan melaksanakan ajaran agama (aliran kepercayaan) yang dianut, termasuk dalam hal ini adalah sikap toleran terhadap pelaksanaan ibadah agama (aliran kepercayaan) lain, serta hidup rukun dan berdampingan.

Pada bagian ini penulis memaparkan hasil pengamatan dan pembahasan dari analisis teks cerpen nasional (Koran Republika) dengan tujuan penelitian, sebagai berikut:

\section{Kearifan Lokal}

Kearifan lokal ialah pikiran-pikiran atau gagasan yang timbul dan berkembang secara terus-menerus di dalam masyarakat berupa nilai-nilai norma, bahasa, adat istiadat, kepercayaan, dan kebiasaan sehari-hari. Juga sebagai salah satu sarana untuk mengolah kebudayaan daerah agar terhindar dari kebudayaan orang asing. Kearifan lokal menurut Susanti (dalam Asriati 2012: 112) ialah gagasan-gagasan setempat yang bersifat bijaksana, penuh kearifan, bernilai baik, yang diikuti oleh anggota masyarakat.

Adapun bentuk-bentuk kearifan lokal yang ditemukan oleh peneliti dalam analisis ini sebanyak enam bentuk. Keenam bentuk tersebut yaitu budaya, norma, etika, kepercayaan, adat-istiadat, dan hukum adat. 
Koentjaraningrat (2002: 45) "Bahwa kata kebudayaan berasal dari bahasa sansekerta Buddhayah, adalah bentuk jamak dari Buddhi yang berarti budi atau akal. Demikian, kebudayaan itu dapat diartikan hal-hal yang bersangkutan dengan budi dan akal. Adapun istilah Culture, sama artinya dengan kebudayaan, yaitu dari kata latin colere yang berarti mengolah atau mengerjakan".

Syahriani (2019) menemukan tiga data budaya pada buku tersebut: (1) putra raja sebagai pewaris tahta; (2) apabila sebuah kerajaan memiliki dua putra sebagai penerus tahta; dan (3) maka Raja harus memilih diantarnya, dan melestarikan benda pusaka. Berbeda dengan penelitian sebelumnya dilakukan oleh Uniawati (2012) yang meneliti tentang kearifan lokal pada pantun sindiran (Apparereseng) masyarakat Bugis, menemukan satu nilai kearifan lokal budaya Bugis yang memberikan sebuah pemahaman tentang bagaimana menata sikap dan perilaku dalam kehidupan bermasyarakat agar senantiasa tetap menghargai pranata yang berlaku dalam kelompok masyarakat penuturnya.

Tim peneliti menemukan data nilai norma. Norma adalah petunjuk tingkah laku yang harus dilakukan dan tidak boleh dilakukan dalam hidup sehari-hari, berdasarkan suatu alasan (motivasi) tertentu dengan disertai sanksi. Sanksi adalah ancaman/akibat yang akan diterima apabila norma tidak dilakukan (Widjaja, 1985: 168).

Syahraini (2019) dalam cerita rakyat pada buku teks Bahasa Indonesia Kelas X edisi revisi 2017 menemukan tujuh data nilai norma. Tujuh data tersebut yaitu: (1) pendidikan tentang agama di usia dini; (2) kewajiban seorang raja membunuh musuh dalam negeri; (3) seorang raja dalam negeri tidak diperbolehkan untuk meninggalkan istana untuk kepentingan pribadi; (4) sapaan adinda dan kakanda yang telah melekat untuk raja dan permaisuri; (5) membersihkan merupakan pekerjaan seorang pelayan di sebuah kerajaan; (6) seorang pelayan bekerja keras untuk mematuhi perintah tuannya dalam keadaan apa pun; dan (7) berkewajiban orang tua memberikan pendidikan yang terbaik untuk anaknya.

Penelitian sebelumnya juga yang dilakukan oleh Uniawati (2012) mengkaji tentang bentuk kearifan lokal pada pantun sindiran (Apparereseng) masyarakat Bugis. Pada penelitian terdapat satu nilai norma, yang menjelaskan pesan orang tua untuk tidak lupa diri dan terburu nafsu dengan kesilapan yang ada sebab belum tentu hal itu membawa kebaikan yang hakiki bagi diri kita sendiri.

Tim peneliti menemukan sebanyak 10 data nilai etika. Etika yaitu Ilmu tentang apa yang baik dan apa yang Yuliantiuk dan tentang hak dan kewajiban moral (akhlak) (Departemen Pendidikan Nasional, 2014).

Syahraini (2019) dalam cerita rakyat pada buku teks Bahasa Indonesia Kelas X edisi revisi 2017 juga menemukan sebanyak empat data nilai etika. Keempat data tersebut terdapat dalam Hikayat Indera Bangsawan yaitu (1) jika memiliki dua putra; (2) maka raja tersebut harus memilih diantara mereka; (3) tidak bergantung kepada makhluk selain kepada Allah Swt.; dan (4) kewajiban orang tua menyelamatkan anaknya dari musuh agar anakya tetap dapat menjadi penerus tahta berikutnya.

Berbeda dengan penelitian ini, terdapat tiga nilai etika yang terdapat dalam penelitian sebelumnya yang dilakukan oleh Uniawati (2012) mengkaji tentang bentuk kearifan lokal nilai etika pada pantun sindiran (Apparereseng) masyarakat Bugis. Nilai etika yang terdapat dalam penelitian sebelumnya mengajarkan untuk bersikap tenang dalam bertindak, menjaga sikap, kehormatan dan harga diri serta menghargai dan menjaga rasa persaudaraan. 
Tim peneliti menemukan 20 data nilai kepercayaan. Kepercayaan berarti anggapan atau keyakinan bahwa sesuatu yang dipercayai itu benar atau nyata (Departemen Pendidikan Nasional: 2014).

Terdapat dua nilai kepercayaan ditemukan oleh Syahraini (2019) pada buku buku teks Bahasa Indonesia Kelas X edisi revisi 2017. Kedua nilai tersebut yaitu: (1) membaca doa qunut dan bersedekah kepada fakir dan miskin, dipercaya akan diberi kemudahan untuk mendapatkan rezeki, salah satunya adalah seorang anak; dan (2) pelestarian terhadap tumbuhan lokal untuk dijadikan sebagai obat-obatan.

Berbeda dengan penelitian ini, nilai kepercayaan yang terdapat dalam penelitian sebelumnya yang dilakukan oleh Uniawati (2012) mengkaji tentang bentuk kearifan lokal nilai kepercayaan pada pantun sindiran (Apparereseng) masyarakat Bugis. Terdapat satu nilai kepercayaan yang terdapat dalam penelitian sebelumnya, mengajarkan bahwa sikap bersyukur harus diterapkan ketika mendapat suatu rezeki apakah itu sedikit atau banyak, baik atau tidak baik.

Tim peneliti juga menemukan sebanyak 5 data bentuk kearifan lokal nilai adat istiadat. Adat-istiadat didefinisika sebagai tata kelakuan yang kekal dan turun-temurun dari generasi satu ke generasi lain sebagai warisan hingga kuat integrasinya dengan pola perilaku masyarakat (Departemen Pendidikan Nasional: 2014).

Syahraini (2019) menemukan sebanyak empat data bentuk kearifan lokal nilai adat-istiadat pada buku teks Bahasa Indonesia Kelas X edisi revisi 2017. Keempat data tersebut yaitu: (1) setiap raja akan mengirim upeti setiap tahun kepada raja yang terkuat; (2) salah satu bentuk penghadapan yang dilakukan masyarakat setempat ketika menghadap kepada raja ialah merendah diri dihadapan raja; (3) berpamitan kepada keluarga dengan cara mengumpulkan anggota keluarga sebelum bepergian jauh; dan (4) saudagar kaya hanya boleh menikah dengan saudagar kaya pula.

Dibandingkan penelitian sebelumnya yang dilakukan oleh Uniawati (2012) mengkaji tentang bentuk kearifan lokal nilai adat-istiadat pada pantun sindiran (Apparereseng) masyarakat Bugis, terdapat satu data nilai adat-istiadat, yang terkandung di dalamnya bahwa seorang gadis hakikatnya harus menjaga nama baik diri dan keluarganya dengan berdiam diri di dalam rumah agar dihormati, dihargai dan tidak menimbulkan fitnah.

Tim peneliti menemukan sebanyak 8 data bentuk kearifan lokal hukum adat. Menurut (Notopuro, 1996: 49) hukum adat adalah hukum tak tertulis, hukum kebiasaan dengan ciri khas yang merupakan pedoman kehidupan rakyat dalam rnenyelenggarakan tata keadilan dan kesejahteraan masyarakat dan bersifat kekeluargaan.

Berbeda dengan penelitian sebelumnya, Syahraini (2019) menemukan sebanyak tiga data bentuk kearifan lokal hukum adat pada buku teks Bahasa Indonesia Kelas X edisi revisi 2017. Ketiga data tersu: (1) pemilik kekuatan terbesar berhak melakukan apa saja; (2) orang yang terhebat di antara kesembilan putra raja berhak menjadi suami putri; dan (3) orang yang dikucilkan atau diasingkan tidak akan mendapatkan perlakuan baik dari dalam negeri tersebut.

\section{Pendidikan Karakter}

Pada bab sebelumnya, tim penulis telah menyajikan data dan menganalisis serta mendeskripsikan nilai pendidikan karakter yang terdapat dalam cerpen nasional (Koran Republika). Pada penelitian terdahulu yang dilakukan oleh Yulianti (2017) pada buku teks Kelas VII SMP/MTs menemukan sebanyak 12 nilai pendidikan karakter yaitu: nilai religius, toleransi, kerja keras, kreatif, rasa ingin tahu, semangat kebangsaan, menghargai prestasi, komunikatif, cinta damai, peduli lingkungan, peduli sosial, dan cinta tanah air. 
Dalam penelitian Syahraini (2019) menemukan sebanyak 48 data dari 13 jenis nilai pendidikan karakter yaitu nilai religius, jujur, kerja keras, kreatif, mandiri, demokratis, rasa ingin tahu, semangat kebangsaan, komunikatif, cinta damai, peduli lingkungan, peduli sosial, dan tanggung jawab.

Menurut Kemendiknas, pendidikan karakter adalah usaha menanamkan kebiasaan-kebiasaan yang baik (habituation) sehingga peserta didik mampu bersikap dan bertindak berdasarkan nilai-nilai yang telah menjadi kepribadiannya. Kemendiknas (2010) juga menyatakan, pembangunan karakter dilakukan dengan pendekatan sistematik dan integratif dengan melibatkan keluarga, satuan pendidikan, pemerintah, masyarakat sipil, anggota legislatif, media massa, dunia usaha, dan dunia industri.

Kajian ini menggunakan pendekatan dengan menggunakan kajian nilai pendidikan karakter yang telah ditetapkan oleh kementrian pendidikan nasional tahun 2010. Oleh karena itu, hasil dan temuan akan diuraikan sebagai berikut.

Salah satu nilai karakter yang tim peneliti temukan pada teks tersebut adalah nilai pendidikan karakter religius. Religius, yakni ketaatan dan kepatuhan dalam memahami dan melaksanakan ajaran agama (aliran kepercayaan) yang dianut, termasuk dalam hal ini adalah sikap toleran terhadap pelaksanaan ibadah agama (aliran kepercayaan) lain, serta hidup rukun dan berdampingan. Terdapat beberapa data yang mengindikasikan sikap religius yang ditampilkan dalam cerpen Indonesia (Koran republika). Syahraini (2019) terdapat enam data yang mengindikasikan sikap religius yang ditampilkan dalam teks cerita rakyat. yaitu: (1) membaca doa qunut; (2) mengaji; (3) berserah diri; (4) peristiwa Allah Swt. menunjukkan kekayaan-Nya; (5) berdoa kepada Tuhan; dan (6) melanggar aturan Allah Swt. Misalnya, dalam cerita rakyat Indera Bangsawan yang melaksanakan ajaran agama yang dianut seperti Raja menyuruh membaca doa qunut agar diberi keberkahan oleh Allah Swt. Raja memberikan pendidikan agama kepada anaknya sejak usia dini, kedua putra raja berserah diri terhadap Allah Swt. atas semua takdir yang dijalani. Kemudian dalam cerita rakyat Hikayat Si Miskin, juga terdapat nilai karakter religius yaitu tentang penggambaran kekuasaan Allah Swt. yang perlihatkan kepada umat-Nya.

Terdapat pula nilai pendidikan karakter dalam teks cerita rakyat Hikayat Bayan Budiman, yaitu Khojan Mubarok yang tak pernah lelah berdoa untuk meminta anak kepada Allah Swt. dan nasihat Burung Tiung tentang sikap dan perilaku yang seharusnya kita kerjakan bersandar pada aturan-aturan agama. Berbeda dengan penelitian sebelumnya yang dilakukan oleh Yulianti (2017) pada buku teks Kelas VII SMP/MTs, nilai religius yang ditemukan sebanyak 12 data. Nilai religius yang ingin ditanamkan pada buku teks tersebut yaitu memesona, sangat indah, menakjubkan, sangat menarik, rasa tentram, elok, pesonanya, memukau, mengagumkan, kenyamanan, kebesaran sang pencipta, dan bersukur.

Nilai pendidikan karakter selanjutnya adalah nilai karakter jujur. Berdasarkan Kementrian Pendidikan Nasional Tahun 2010 mengartikan jujur sebagai perilaku yang didasarkan pada upaya menjadikan diri sebagai orang yang selalu dapat dipercaya dalam perkataan, tindakan, dan pekerjaan. Tim Peneliti menemukan data nilai jujur, yaitu ..Syahraini (2019) menemukan dua data nilai jujur yang ditemukan pada buku teks Bahasa Indonesia Kelas X edisi revisi 2017, yaitu: (1) dalam teks Hikayat Indera Bangsawan, menunjukkan seorang tabib yang tidak akan berbohong mengenai obat yang ia peroleh; dan (2) menunjukkan obat yang sebenarnya.

Kerja keras yaitu perilaku yang menunjukkan upaya secara sungguh-sungguh (berjuang hingga titik darah penghabisan) dalam menyelesaikan berbagai tugas, permasalahan, pekerjaan, dan lain-lain dengan sebaik-baiknya. Syahraini (2019) 
menemukan lima data nilai karakter kerja keras pada buku teks Bahasa Indonesia Kelas $\mathrm{X}$ edisi revisi 2017, yaitu: (1) bersungguh-sungguh dalam menyelesaikan tugas; (2) bersungguh-sungguh mendapatkan putri raja; (3) mencari kalung; (4) mencari rezeki, dan (5) membuat senang hati istri. Terdapat Hikayat Indera Bangsawan yaitu perjuangan Syah Peri dan Indera Bangsawan dalam mencari buluh perindu demi menjadi raja di istana, kesungguhan kesembilan anak raja dalam menyembuhkan putri raja, usaha Indera Bangsawan dalam mendapakan Tuan Putri.

Dalam Hikayat Bunga Kemuning, yaitu Raja yang bersungguh-sungguh dalam mencari kalung berwarna kuning untuk Putri Kuning. Dalam Hikayat Si Miskin, yaitu kerja keras si Miskin dalam mencari rezeki, dan usaha si Miskin dalam memberikan kebahagiaan untuk istrinya. Berbeda dengan penelitian sebelumnya yang dilakukan oleh Yulianti (2017) pada buku teks Kelas VII SMP/MTs, terdapat satu data nilai kerja keras yang ingin ditanamkan pada buku teks tersebut yaitu sikap dan tindakan sungguhsungguh untuk menyelesaikan tugas mengumpulkan makanan dengan sebaik-baiknya.

Selanjutnya, Syahraini (2019) juga menemukan sebanyak dua data nilai karakter kreatif pada buku teks Bahasa Indonesia Kelas X edisi revisi 2017. Kreatif, yakni sikap dan perilaku yang mencerminkan inovasi dalam berbagai segi dalam memecahkan masalah, sehingga selalu menemukan cara-cara baru, bahkan hasil-hasil baru yang lebih baik dari sebelumnya. Data tersebut yaitu: (1) mencari muslihat; dan (2) mencari ramuan. Terdapat dalam Hikayat Indera Bangsawan yaitu ide sang raja dalam memilih seorang raja dengan mengadakan sayembara untuk mengetahui yang paling kuat di antara putranya dan muslihat Indera Bangsawan dalam mengalahkan Buraksa. Berbeda dengan penelitian sebelumnya yang dilakukan oleh Yulianti (2017) pada buku teks Kelas VII SMP/MTs, terdapat satu data nilai kreatif yang ingin ditanamkan pada buku teks tersebut yaitu dapat melakukan sesuatu dari bakat yang dimiliki.

Syahraini (2010) menemukan dua data nilai karakter mandiri pada buku teks Bahasa Indonesia Kelas X edisi revisi 2017, yaitu: (1) tak terlihat manja dan nakal; serta (2) takut meminta-minta. Mandiri yaitu sikap dan perilaku yang tidak tergantung pada orang lain dalam menyelesaikan berbagai tugas maupun persoalan. Namun hal ini bukan berarti tidak boleh bekerja sama secara kolaboratif, melainkan tidak boleh melemparkan tugas dan tanggung jawab kepada orang lain. Data yang mengungkapkan nilai mandiri terdapat dalam Hikayat Bunga Kemuning yaitu Putri Kuning memiliki sifat yang tidak bergantung kepada orang lain, juga terdapat dalam Hikayat Si Miskin yaitu si Miskin yang hidupnya tidak bergantung pada orang lain.

Demokratis yakni sikap dan cara berpikir yang mencerminkan persamaan hak dan kewajiban secara adil dan merata antara dirinya dengan orang lain. Nilai demokratis tim peneliti temukan sebanyak data yakni: ........Nilai demokratis juga Syahraini (2019) temukan sebanyak dua data, yaitu; (1) memberikan baju sesuai dengan nama anak; dan (2) meminta keadilan. Terdapat dalam Hikayat Bunga Kemuning, yaitu Raja memberikan pakaian dan barang kepada kesepuluh putrinya tersebut sesuai dengan nama warna mereka, dan kakak-kakak Putri Kemuning yang seharusnya tidak berhak mendapatkan hadiah karena telah bersikap yang tidak baik.

Rasa ingin tahu yaitu cara berpikir, sikap, dan perilaku yang mencerminkan penasaran dan keingintahuan terhadap segala hal yang dilihat, didengar, dan dipelajari secara lebih dalam. Sebanyak 7 data nilai rasa ingin tahu yang tim peneliti temukan dalam cerpen nasional (Koran Republika). Sebanyak enam data nilai Rasa ingin tahu yang peneliti temukan dalam buku tersebut, yaitu: (1) bertanya perihal oleh-oleh, (2) bertanya perihal kejadian yang terjadi, dan (3) bertanya perihal kehendak. Terdapat dalam Hikayat 
Bunga Kemuning, yaitu Raja yang penasaran dengan barang yang diinginkan putriputrinya. Kemudian terdapat pula dalam Hikayat Si Miskin, yaitu rasa ingin tahu dari Syah Alam atas keributan yang terjadi di luar istana, penjual buah yang ingin mengetahui maksud kedatangan si Miskin ke tempatnya, dan Raja yang penasaran dengan keberanian si Miskin datang ke istana. Berbeda dengan penelitian sebelumnya yang dilakukan oleh Yulianti (2017) pada buku teks Kelas VII SMP/MTs, terdapat satu data nilai rasa ingin tahu yang ingin ditanamkan pada buku teks tersebut yaitu berupaya mengetahui lebih mendalam tentang sesuatu yang dilihat dan didengar atau petualangan.

Tim Peneliti juga menemukan nilai karakter semangat kebangsaan atau nasionalisme yaitu sikap dan tindakan yang menempatkan kepentingan bangsa dan negara di atas kepentingan pribadi atau individu dan golongan. Syahraini (2019) menemukan nilai karakter semangat kebangsaan atau nasionalisme, yaitu Sebanyak tiga data nilai semangat kebangsaan yang peneliti temukan dalam buku tersebut, yaitu: (1) belajar ilmu senjata; (2) menjaga kedamaian negeri; dan (3) sibuk dengan kepemimpinan. Terdapat dalam Hikayat Indera Bangsawan, yaitu semangat Syah Peri dan Indera Bangsawan dalam mempelajari ilmu senjata, Raja Kabir yang rela menukarkan putrinya demi keselamatan negerinya. Juga dalam Hikayat Bunga Kemuning yaitu sang Raja yang lebih mementingkan mengurus negerinya dibanding anak-anaknya. Berbeda dengan penelitian sebelumnya yang dilakukan oleh Yulianti (2017) pada buku teks Kelas VII SMP/MTs, terdapat dua data nilai semangat kebangsaan. Semangat kebangsaan yang ingin ditanamkan pada buku teks tersebut yaitu sikap memposisikan diri dengan menunjukkan kesetiaan dan merawat negeri.

Komunikatif, senang bersahabat atau proaktif, yakni sikap dan tindakan terbuka terhadap orang lain melalui komunikasi yang santun sehingga tercipta kerja sama secara kolaboratif dengan baik. Tim Peneliti juga menemukan data nilai karakter komunikatif sebanyak 3 data. Syahraini (2019) menemukan data nilai karakter komunikatif sebanyak dua data, yaitu: (1) raksasa dijadikan sebagai nenek; dan (2) terbuka kepada orang lain. Terdapat dalam Hikayat Indera Bangsawan, yaitu keakraban antara Indera Bangsawan dan Nenek Raksasa akibat komunikasi mereka yang lebih daik dan lebih dekat, juga terdapat dalam Hikayat Si Miskin yaitu si Miskin yang selalu menjaga komunikasi dengan istrinya dengan cara menceritakan segala apa yang terjadi terhadapnya. Berbeda dengan penelitian sebelumnya yang dilakukan oleh Yulianti (2017) pada buku teks Kelas VII SMP/MTs, terdapat sebanyak empat nilai komunikatif. Nilai komunikatif yang ingin ditanamkan pada buku teks tersebut yaitu sikap semangat, ceria, saling merangkul, dan memaafkan.

Tim Peneliti juga menemukan data nilai karakter cinta damai sebanya 4 data Syahraini (2019) juga menemukan sebanyak enam data nilai karakter cinta damai, yaitu: (1) bersikap tenang; (2) riang dan ramah; (3) sabar; (4) lemah lembut; (5) membuatkan teh dan (6) menenangkan. Cinta damai yakni sikap dan perilaku yang mencerminkan suasana damai, aman, tenang, dan nyaman atas kehadiran dirinya dalam komunitas atau masyarakat tertentu. Terdapat dalam Hikayat Indera Bangsawan, yaitu Indera Bangsawan bertemu dengan sang Raja secara santun dan damai untuk memberikan obat penawar Putri Kemala Sari. Juga dalam Hikayat Bunga Kemuning, yakni Putri Kuning yang memiliki sifat ramah dan periang juga suka bersosialisasi, sabar dan tabah menghadapi perilaku saudaranya terhadap dia, juga tenang dalam menyelesaikan masalah. Juga terdapat dalam Hikayat Si Miskin, yaitu sikap si Miskin yang berusaha menenangkan istrinya yang sedang bersedih. Berbeda dengan penelitian sebelumnya yang dilakukan oleh Yulianti (2017) pada buku teks Kelas VII SMP/MTs, terdapat sebanyak lima data nilai 
cinta damai. Cinta damai yang ingin ditanamkan pada buku teks tersebut yaitu sikap hormat dan bahagia, sangat baik, ramah dan lembut, serta sabar.

Peduli lingkungan, yakni sikap dan tindakan yang selalu berupaya menjaga dan melestarikan lingkungan sekitar. Tim Peneliti menemukan nilai karakter peduli lingkungan sebanyak 3 data. Syahraini (2019) menemukan sebanyak tiga data nilai karakter peduli lingkungan, yaitu (1) menjaga kebersihan; (2) merangkai bunga; (3) dan memelihara Burung di rumah. Terdapat dalam Hikayat Bunga Kemuning, yaitu Putri Kuning menjaga taman kesayangan ayahnya, dan ia mencintai keindahan dengan merangkai bunga. Juga dalam Hikayat Bayan Budiman, yaitu Khojan Maimun memiliki sikap yang berupaya menjaga lingkungan sekitar dengan cara merawat sepasang Burung Bayan. Berbeda dengan penelitian sebelumnya yang dilakukan oleh Yulianti (2017) pada buku teks Kelas VII SMP/MTs, terdapat tiga data nilai peduli lingkungan. Nilai peduli lingkungan yang ingin ditanamkan pada buku teks tersebut yaitu sikap kenyamanan, banyaknya wisatawan, dan melingdungi lingkungan laut.

Tim peneliti menemukan data nilai karakter peduli sosial sebanyak 5 data. Syahraini (2019) juga menemukan enam data nilai karakter peduli sosial. Peduli sosial, yakni sikap dan perbuatan yang mencerminkan kepedulian terhadap orang lain maupun masyarakat yang membutuhkannya. Data tersebut yaitu: (1) tolong-menolong; (2) peduli kepada orang tua; (3) saling mengasihi; (4) \& (5) peduli kepada istri; dan (6) memberikan makan kepada orang miskin; Terdapat dalam Hikayat Indera Bangsawan, yaitu Syah Peri yang bertarung melawan Garuda untuk menolong Putri Ratna Sari beserta dayangdayangnya. Terdapat pula dalam Hikayat Bunga Kemuning, yakni kepedulian akan keselamatan ayah Putri Kemuning lebih ia harapkan dibanding dengan hadiah apa pun. Juga terdapat dalam Hikayat Si Miskin, yakni istri yang setia terhadap suaminya bagaimana pun keadaanya, dan si Miskin yang selalu peduli dengan kebahagiaan istrinya, kepedulian masyarakat terhadap si Miskin dengan memberikan buah, makanan, dan pakaian. Berbeda dengan penelitian sebelumnya yang dilakukan oleh Yulianti (2017) pada buku teks Kelas VII SMP/MTs, terdapat sebanyak dua data nilai peduli sosial. Nilai peduli sosial yang ingin ditanamkan pada buku teks tersebut yaitu sikap memberiikan bantuan kepada orang lain atau tolong menolong.

Tanggung jawab, yakni sikap dan perilaku seseorang dalam melaksanakan tugas dan kewajibannya, baik yang berkaitan dengan diri sendiri, sosial, masyarakat, bangsa, negara, maupun agama. Tim Peneliti menemukan data nilai karakter tangggung jawab sebanayak 3 data. Syahraini (2019) menemukan sebanyak dua data nilai karakter tanggung jawab, yaitu: (1) pemimpin yang menjaga negeri; dan (2) tanggung jawab suami mencari nafkah. Terdapat dalam Hikayat Indera Bangsawan, yaitu tanggung jawab Raja terhadap negeri yang sedang dipimpin, ia harus menyerahkan putrinya terhadap Buraksa demi keselamatan negerinya. Juga terdapat dalam Hikayat Si Miskin, yakni tanggung jawab si Miskin terhadap istrinya untuk memberiikan nafkah.

\section{Simpulan}

Berdasarkan hasil analisis data, disimpulkan bahwa penelitian cerpen di Indonesia ini menghasilkan bentuk kearifan lokal dan pendidikan karakter. Jenis kearifan lokal yang ditemukan pada cerpen Indonesia yaitu budaya, norma, etika, kepercayaan, dan adat istiadat. Implikasi pembelajaran cerpen Indonesia pada pengajaran Prosa Fiksi adalah sangat mendasar dalam pemahaman mahasiswa di perguruan tinggi. 


\section{Ucapan Terima Kasih}

\section{Daftar Pustaka}

Andriani. 2016. “Peningkatan kemampuan Menganalisis Unsur Instrinsik Cerpen dengan Model Inside Outside Circle Siswa Kelas XI IPA 2 SMA Negeri 1 Polewali kabupaten Polewali mandar. Jurnal Pepatuzdu, Vol. 11, No.1.hal 23.

Asriati, Nuraini. 2012. Mengembangkan Karakter Peserta Didik Berbasis Kearifan Lokal Melalui Pembelajaran di Sekolah. Jurnal Pendidikan Sosiologi dan Humaniora. Vol. 3,No. 2.

Ba, S. and Pavlou, P.A. 2002. "Evidence of the effect of trust building technology in electronic markets: price premiums and buyer behaviour". MIS Quarterly, Vol. 26, No. 3

Bagus, Lorens. 2000. kamus filsafat. Jakarta: PT Gramedia Pustaka.

Bur, Eka Yulianti. 2017. Analisis Nilai-Nilai Pendidikan Karakter Dalam Buku Teks Kelas Vii Smp/Mts: Kajian Semiotika Charles Sanders Peirce. Skripsi. Makassar: Universtas Negeri Makassar.

Cecep, Raden. 2011. Kearian Lokal tetang Mitigasi Bencana pada Masyarakat Buduy. Jurnal Makara, Sosial Humaniora. Vol. 15. No. 1.

Daniah. 2016. Kearifan Lokal (Local Wisdom) sebagai Basis Pendidikan Karakter. Jurnal Pendidikan. Vol. 5,No. 2.

Departemen Pendidikan Nasional. 2014. Kamus besar bahasa Indonesia edisi IV. Jakarta: Gramedia Pustaka Utama

Departemen Sosial RI. (2006). Memberdayakan Kearifan Lokal bagi Komunitas Adat Terpencil.

Fajarini, Ulfah 2014. Peranan Kearifan Lokal dalam Pendidikan Karakter. Social Science Education Journal. Vol. 1,No.2.

Hasbullah, Bakry. 1978. Sistematika Filsafat. Jakarta: Wijaya.

Irwan, Abdullah 2009. konstruksi dan reproduksi kebudayaan. Yokyakarta: Pustaka Pelajar.

Jayapada. 2017. Kearifan Lokal dalam Cerita Rakyat sebagai Media Pendidikan Karakter untuk Membentuk Literasi Siswa. Jurnal Kajian Perpustakaan dan Informasi. Vol. 1, No. 2.

Kementrian Pendidikan Nasional. 2010. Pelaksanaan Pendidikan Karakter. Jakarta: Badan Penelitian dan Pengembangan Pusat Kurikulum dan Perbukuan.

Keraf. A. Sonny. 2002. Etika Lingkungan. Jakarta: Penerbit Buku Kompas.

Khomsilawati, Saktya. 2017. Penguatan Karakter Religius dalam Pembelajaran Sastra Melalui Adaptasi Kearifan Lokal. Prosiding Seminar Nasional Bahasa dan Sastra Indonesia. Vo. 1 no. 1 
Kosasih, E. 2012. Dasar-dasar Kerampilan Bersastra. Bandung: Yram Widya.

Lestari Sri, dkk. 2014. "Analisis Unsur Intrinsik dan Ekstrinsik pada Kumpulan Cepen Pilihan Kompas 2014 serta Relevansinya sebagai materi Pembelajaran sastra di Sekolah Menengah Atas." Jurnal Penelitian Bahasa, sastra Indonesia dan Pengajarannya 4 (1): 197-198.

Manurung, Rosida Tiurma. 2010. "Peranan Sastra dalam Pemertahanan Nilai-Nilai Budaya Lokal sebagai Pemerkukuh Identitas dan Ketahanan Bangsa dalam Era Globalisasi". Prosiding Kongres Internasional Bahasa-Bahasa Daerah Sulawesi Tenggara, 18-20 Juli 2010 Di Bau-Bau. Kendari: Kantor Bahasa Provinsi Sulawesi Tenggara.

Mokoginta, J. C. (1996). Adat Istiadat Etnik Bolaang Mongondow : Etnik Budaya dan Perubahan. Jakarta : Yayasan Bogani Karya.

Mulyasa. 2011. Manajemen Pendidikan Karakter. Jakarta: Bumi Aksara.

Nurgiantoro, Burhan. 2015. Teori Pengkajian Fiksi. Yogyakarta: Gadjah Mada University Press.

Notopuro, Hardjito. 1996. "Tentang Hukum Adat, Pengertian dan Pcrnbahasan dalam Hukum Nasional" Majalah hukum Nasional. Nomor 4, Hal. 49. Jakarta.

Singgih, D Gunarsah. 2004. Psikologi Perkembangan Anak dan Remaja. Jakarta: Gunung Mulia.

Syamsiar. 2010. Bentuk-Bentuk Kearifan Lokal Dalam Kehidupan Masyarakat Indonesia Sebagai Sumber Gagasan Berkarya Seni Rupa. Jurnal Kajian Teori, Praktik, dan Wacana Seni Budaya Rupa. Vol.2 No.1.

Uniawati. 2012. Nilai-Nilai Kearifan Lokal Pantun Sindiran (Apparereseng) Bugis: Tinjauan Hermeneutik. Prosiding Seminar Bahasa-Bahsa Daerah Sulawesi Selatan 14 Oktober 2012. Makassar: Kantor Bahasa Provinsi Sulawesi Tenggara.

Van, Vollenhoven. 1987. Penemuan Hukum Adat. Jakarta : Djambatan

Wellek, Rene dan Austin Warren. 1956. Theory of Literare. New York. Harcourt, Brace \& World. Inc (terjemahan dalam Bahasa Indonesia oleh Melani Budiyanto. 2014. Teori Kesusasteraan. Jakarta: Gramedia).

Wibowo, Agus \& Gunawan. 2015. Pendidikan Karakter Berbasis Kearifan Lokal di Sekolah. Konsep, Strategi dan Implementasi. Yogyakarta: Pustaka Pelajar.

Wicaksono, Andri. 2017. Pengkajian Prosa Fiksi (edsisi Revisi). Yogyakarta: Penerbit Garudhawaca.

Widjaja, AW. 1985. Kesadaran Hukum Manusia dan Masyarakat Pancasila. Jakarta: Era Swasta.

Yahya, Muhammad. 2016. Nilai Pendidikan Karakter dalam Novel 5 CM Karya Donny Dhirgantoro dan Implementasinya dalam Pembelajaran Bahasa dan Sastra Indonesia di Kelas VIII SMP. Skripsi. Makassar: Universitas Negeri Makassar.

Zuchdi, Darmiyati. 2008. Humanisasi Pendidikan. Jakarta: PT. Bumi Aksara. 